\title{
The Use of Language Game in Enhancing Students' Speaking Skills
}

\author{
Dalvinder Kaur, Azlina Abdul Aziz
}

To Link this Article: http://dx.doi.org/10.6007/IJARBSS/v10-i12/8369

DOI:10.6007/IJARBSS/v10-i12/8369

Received: 10 October 2020, Revised: 16 November 2020, Accepted: 30 November 2020

Published Online: 24 December 2020

In-Text Citation: (Kaur \& Aziz, 2020)

To Cite this Article: Kaur, D., \& Aziz, A. A. (2020). The Use of Language Game in Enhancing Students' Speaking Skills. International Journal of Academic Research in Business and Social Sciences, 10(12), 687-706.

\section{Copyright: (c) 2020 The Author(s)}

Published by Human Resource Management Academic Research Society (www.hrmars.com)

This article is published under the Creative Commons Attribution (CC BY 4.0) license. Anyone may reproduce, distribute, translate and create derivative works of this article (for both commercial and non-commercial purposes), subject to full attribution to the original publication and authors. The full terms of this license may be seen at: http://creativecommons.org/licences/by/4.0/legalcode

\section{Vol. 10, No. 12, 2020, Pg. 687 - 706}

Full Terms \& Conditions of access and use can be found at http://hrmars.com/index.php/pages/detail/publication-ethics 


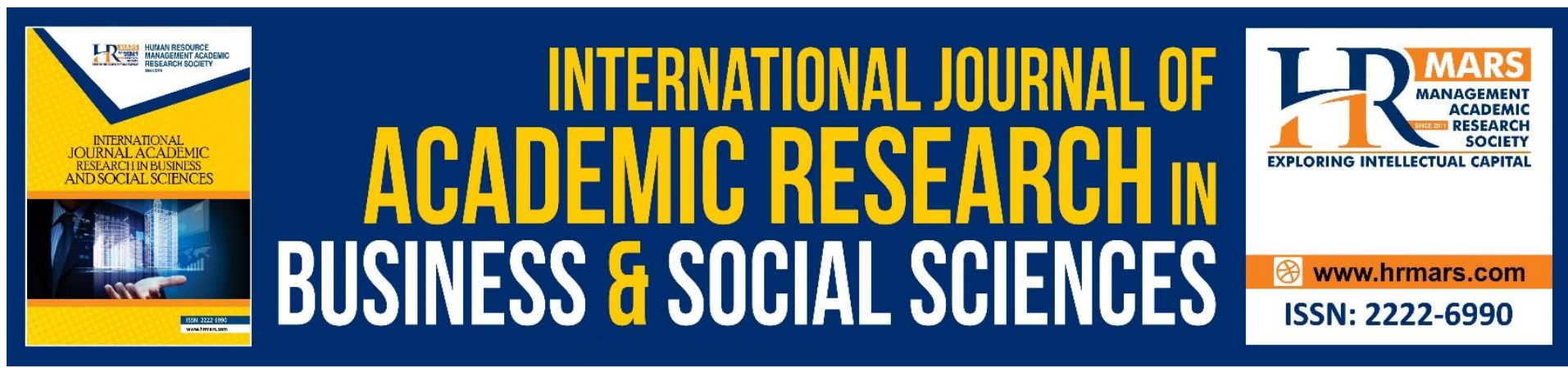

\title{
The Use of Language Game in Enhancing Students' Speaking Skills
}

\author{
Dalvinder Kaur \\ Faculty of Education, The National University of Malaysia \\ Email: dalvinsidhu01@gmail.com

\section{Dr. Azlina Abdul Aziz} \\ Faculty of Education, The National University of Malaysia \\ Email: azlina1@ukm.edu.my
}

\begin{abstract}
This paper consist of systematic review on published past related studies on the use of language games in enhancing students' speaking skills from the year 2010 to 2019. The main objective of this systematic review is to present synthetic evidence found in past related studies on influence of language games in improving English as Second Language learners' speaking skills to researcher and reading educators so that the further implementation and development research in this area can be conducted. This systematic study attempt to find answer for two questions research i.e how effective is language games in improving students' speaking skills and what are the students' experience when playing the game. The results of these study illustrates the importance and positive impact of language games in enhancing students speaking skills. Recommendations and limitations are further discussed.
\end{abstract}

Keyword: Language Games, Speaking Skills, English As Second Language, Learner's Experience, Systematic Review

\section{Introduction}

Human communication is a complex process (Harmer, 2007). Yet communicating is a vital part of human life. Language consist of four skills which is reading, writing, listening and speaking, speaking is used as twice more than reading and writing skills (Rivers, 1981).Speaking and writing is categorized as productive skills whereas reading and listening is labelled as receptive skills(Torky,2006).Speaking and listening are skills that are co-dependent with one another. Through a conversation we need to listen attentively in order to reply the speech or express our thoughts (Educational leadership, 2008).Speaking and listening skills are used daily in various settings in order to complete daily task including to solve problem, to achieve a purpose and to inform (Wye, 2004). According to (Oprandy, 1994:Menoufy, 1997), speaking and listening occurs at the same time thus every speaker is a listener and every listener is a speaker. 
Speaking involves communicating about their opinions and ideas loudly. Our ability to speak , listen and understand people's speech are skills that we mould by observation and practicing on what we see some skills and language are taught through education so we can fit in the era of globalization (Ahmad, 2016).A person that knows the language is refer as a 'speaker' (Torky, 2006). To ensure the process of communication is carried out smoothly, the flow of communication must be smooth. To maintain this situation the speaker should be able to communicate clearly, effectively, fluently and dynamically (Ahmad, 2006).

There are a lot languages used around the world, but all of us share one common language which is the International language English. In most of the countries, English is use as second language including Malaysia. Somehow, English is taught and spoken in non-native countries (Qureshi, n.d). Even though English hold a second position in many countries but it is widely use in various sector such as medicine, education, engineering, higher institute, business, technology, banking and many more sectors (Qureshi, n.d).Even in digital world English is widely used. English also has penetrate the world of economic and social. English has a massive role in our life, so it is very essential to have the ability of English speaking skills.

Learning English as foreign language not only help speakers to understand the language but also helps to understand their culture (Diana, 2012). Learners will gain more knowledge and perhaps will develop better understanding of learners own culture in a different view. Understanding and respecting different cultures can develop better connection and can fill the gap between cultures(Diana,2012).It also provide opportunity to be directly involve with other people's culture hence it will helps to build awareness of global community (Curtain \& Dahlberg, 2004; Darwish et al., 2020).

In addition, through learning foreign you can develop yourself by shaping your identity(Diana,2012). Moreover, nowadays most of the companies demand the knowledge of English, being proficient in English gives a chance to stand out in the competitive world (Villano, 1996).Learning English also comes quite in handy when travelling to other countries. Speaking English in non-native English countries is a basic survival kit.

Knowing to speak English fluently allow learners to build bigger circle of friends because they are able to communicate with more people (Diana, 2012).Furthermore, when learners communicate with people using the language that is prominent to them, they tend to be more comfortable with the conversation thus it foster their relationship. Learning English helps learners to develop native language (Diana, 2012). Learners tend to have better vocabularies through learning English as foreign language (Mirebella \& Ariana, 2013).Studying a foreign language from young age till higher education develop learners with accuracy, fluency and a strong grip of vocabularies which leads to broaden their perspective academically (Pop, 2011).Speakers that speaks second language are more creative and use their high thinking skills to solve complicated problems compared to those who do not know second language(Bamford\&Mizokawa,1991). Even though there will be differences of grammar, sentence structure between the two languages, but learners can readily transfer between two languages through academic and cognitive skills (Mirebella \& Ariana, 2013).In short, learning second language helps to enhance memory, critical thinking, social and study skills(Mirebella \& Ariana, 2013).

The need of English heightens when English become the international language. English is spoken by a quarter of countries in the world (British Council, n.d).English has become the global demand and a need for economic, business and social development of a country(Pinon \& Haydon, 2010).Thus it is very essential for a individual to have a good speaking proficient in order to gain prosperity in life. 
Even though speaking English is really important but conducting speaking lessons can tough at times no matter which level of learners. Teachers faced a lot of challenges to teach speaking. Speaking is one of the difficult skills to learn .Not only teachers even learners face difficulties to learn speaking in English. Mostly learners feel demotivated to learn the language due the teaching methods. There are also learners faced anxiety and feel shy to speak in front of the classroom. Teachers need to implement methods and activities to minimize the challenges faced during teaching and learning speaking skills. For speaking lessons, teacher must ensure students get the opportunity to speak in class hence teachers can use communicative approach which focuses real communication (Harmer, 2001). Instead of focusing to the structure of the language, teachers need to focus on function of the language (Harmer, 2001). Still teacher must be able to attract learners' attention by having interesting and fun activities which motivates them to speak voluntarily in the class (Harmer, 2004).Games is one of the solution to teachers' problems in teaching speaking. Teacher can helps learners to use communicate English in real situations through games instead on just focusing on the structure of language (Littlewood, 1981).

Games can promise full participants of students in classroom because it is fun and they can enjoy while learning (Mahmoud\& Tanni, 2014). Everyone loves to win, so game can develop a healthy competitive platform for students to speak English. In order to win or complete the task they have express and understand people's point in English as well as take actions by saying or doing in English (Gate, 2003). So games helps students to practice all main skills of language, all stages of the teaching and learning and various kind of speaking skills (Betterigde \& Bucky, 2006). Games promotes learners to think creatively without realizing it. According to psychologist Piaget (2001), movement produces 'thought' which initiates the learning process and the responsible joint that built up cognitive frame is the movement not consciousness.

Language game is fusion of language and play (Rooyackers, 2002). Passive learners can get the chance to speak in classroom through games. Games are also suitable for low proficiency learners as they won't feel pressure while learning English in a fun way. So they feel more relaxed and feel free to accept the input from the teacher. Hence it motivates them to learn English as second language (Hubbard, 1987).

There are games that boost teamwork. Implementation of games in classroom allows learners to communicate with each other, some games are played in groups. Therefore learners need to interact with each other in order to complete the task given. Teacher should observe the learners and take actions if learners are not cooperating with their teammates. From this situation learners learn the value working together. It also gives a chance to students to mix around with their peers.

Games can be design to cater the learners' need. There are few factors teacher need consider before using games in lessons. Firstly teacher must know which game fits into the lesson and curriculum (Harris, 2006). Teacher must matches the objectives of the games with the learning out of the lesson (Mackenty, 2006). At the end of lesson, goals of game and lesson should be achievable by the learners. Teacher should use the suitable game which meet the language skills, for example, playing guessing games to enhance learners' speaking ability. The game be only a success when learners are able to have a certain level of language proficiency. Other than that teacher need to make rules which fit the learners' capability. In short clear rules, achievable goals, a quick feedback are the main elements of a successful language game (Hong, 2002). 


\section{Poor Speaking Skills among ESL Learners}

Teachers and learners always faced challenges during teaching and learning process of speaking English as a second language. Speaking fluently means having good vocabulary, pronunciation and grammar which is difficult for a learner to master it all due to few factors. Some past related studies proves that there are factors affecting the teaching and learning process of English. In Kandahar University, there are number of poor English speakers although learners been taught English for twelve years in school and additionally four years in university (Rahimi \& Qureshi, 2019). Despite all these years of learning to speak English, they are still categorize as low proficient English learners. Similar study reported, the proficiency of English is very low among university learners (Kasim, 2003). Based on the findings, learners experience no confidence in speaking English, they can't even talk to their parents in English (Rahimi \& Qureshi, 2019). Language learners expect someone to help them out either directly or indirectly to learn a new language, but at times they are often misunderstood when they do mistakes (Baker \& Westrup, n.d). Hence learners becomes paranoid about making mistakes in front of people therefore they lose their confident level in speaking English (Baker \& Westrup, n.d).

According to Harry Ayers (2006), learners faced anxiety and depression which makes learning become difficult. Language anxiety refers to learners experience the feeling of tension and fear in classroom (Nur etc al, 2019). Language anxiety is build up from typical self-perceptions ,beliefs, feelings and behavior towards language learning in classroom(Darmi\&Albion,2013). These kind of learners develops discomfort, nervousness and shyness in class(Nur etc al, 2019). They automatically decide to be silent in English lessons in order to safe themselves from making mistakes in front of their peers. This situation makes them become passive learners and it affects the way they learn to speak in English as learning speaking English requires a lot of practice.

Making mistakes when learning a new language is common but making consistent mistakes can affect learners in a lot of way as their self-esteem, confidence, attitude and motivation (Hamad, 2013).There is also related study conducted in Malaysia with higher institute learners, based in an interview learners stated feeling of nervous and unsure about speaking English is the cause of them being passive in class(Nur et al, 2019).The method of teaching can affects learners' attitude of learning speaking skills. Teachers play essential role to shape learners' speaking development. In speaking body language, gestures, facial expressions, vocal projection, speaking rate and enunciation holds a prominent role and teacher is responsible to correct the students or teach all these elements in speaking.

Although speaking is an important skills but it is often ignored because learning second language is very exam-oriented. Most of the exams focuses on writing and reading skills. So teachers give more attention to teach writing and reading skills in order to pass the examination. The importance of learning to speak English is minimized (Baker \& Westrup, n.d). There is also study in Malaysia reported that learners do not like to come from their comfort zone, which means they prefer using their native language rather than learning a foreign language (Ridwan \& Zahariah, 2017). They won't put effort to learn English and this form a major challenge to teachers. The same study report, learners faced difficulties to understand the content of the topic as the educators explains the topic very fast (Nur et al, 2019). Educators should consider learners' proficiency background before teaching. This situation gives an impact to learners' interest, when they fail to understand the topic they tend to lose interest and focus in classroom. There are also learners with limited vocabulary 
when they go to higher institution and educators use various vocabulary, learners do not understand and affects their speaking skills (Rani, 2013).

Learners' native language and English are different structural. Just because learners are used to speak their mother tongue, they tend to direct translate from their mother tongue to English and this make their speech structurally incorrect. This situation occurs because have lack of grammatical pattern understanding (Darmi, 2013). In short, there are three main factors, cultural, linguistic and psychological that affects learners' to learn speaking English as second language (Kukulska-Hulme et al., 2011).

\section{Research Objectives and Research Questions}

The main objective of this systematic review is:

- To present synthetic evidence found in past related studies on language games helps to improve ESL learners' speaking skills.

This study conducted to answer two research questions:

(a) How effective is language games in improving learners' speaking skills?

(b) What are the learners' experience when playing the game?

\section{Literature Review \\ Definition of Speaking}

Speaking is an action that involves words to utter, those words or sentences are person's thoughts that been said loudly. Speaking is a skill that is very essential in a language which can be first or second language. Through speaking, we can measure the success of a language proficiency (Thornbury, 2005 ;Nunan, 1995).Thus, speaking is really emphasize when learning a foreign language. Speaking is more used and learned compare to other language skills as writing, listening and reading in learning second or foreign language (Thornbury, 2005; Nunan, 1995).Speaking is a skill that is noticeable compare to other skills, people would notice the way speakers speak before notice reading, writing or listening skills. Therefore, learners of second language must master the vocabulary and syntax of sentence structure because speaking is all about using the accurate words to express thoughts.

Speaking is a norm for humans as they use it so much in their daily life. It is stated that, an average person produces tens of thousands words a day (Thornbury, 2005; Nunan, 1995). However, people in different professional which involves speaking produces more amount of words than a way such as people who work sales, educators, promoters.

The objective of speech is depend on the speakers' personal goal. There are few components of speaking that learners of second language have to pay attention. Phonology is one of the component that can be tough to be master for speakers that are learning second language, as they have be aware of all the pronunciation of words(Thornbury, 2005; Nunan, 1995).There are words in English which is not pronounce the way it is spell thus it confused the learners. The speed of speech is one of the important component in speaking because speaker must know what rate of speed they need to be in, to ensure there is sufficient time of processing or outgoing speech. New speakers need to monitor their output, they must always gain their feedback from interlocutors on their speech to observe their progress (Thornbury, 2005; Nunan, 1995).

All these factors make speaking a challenging skill to be learn however many people view speaking as central skill. The desire to communicate with others in real time and to stay connected face to face motivates people to master English fluency and accurately (Thornbury, 2005; Nunan, 1995). 


\section{Role of Teacher in Speaking Class}

In speaking class, one of teacher's role is to communicate with students and provide them a feedback on their speaking. Speaking is one of the very important skill for human as it would be difficult to live without communicating either in monologues or dialogues (Harmer, 2001).Teacher in speaking class have to face many challenges, when students have complication in speaking. In speaking class, student are ought to speak but many of them experience anxiety or shyness to speak in second language in classroom. So teacher could not really monitor their progress of speech because speaking is all about practicing it out. Thus, teacher have to put in a little extra effort to ensure students speak in the classroom (Harmer, 2001).Teacher plays an important role in helping students' to master speaking English.

Teacher holds major role to facilitate communication in classroom hence teacher should play three different roles in teaching speaking which is prompter, participant and feedback provider (Harmer, 2001). Those roles are explained briefly as follow according Harmer (2001):

(a) Prompter: Sometimes students in speaking task do not have that much of depth of knowledge that they have newly learn therefore during speaking they might have long pause because they can't think what to say next so in way they lose fluency and flow of the of speech. Teacher can just leave them to struggle and find their own way to complete the speech or offer suggestion. Teacher would be able to see a better progress if the teacher give a little assist to students.

(b)Participant: When assigning speaking task to students, teacher should be good animators and participate together to show them how is it done. This also would foster student and teacher relationship. Teacher should prompt, assist students to carry out speaking activity smoothly. Students are able to learn new information. However, teacher should always bear in mind not to participate too much so they would depend fully on the teacher. Teacher have to balance the amount of speaking between teacher and students.

(c)Feedback provider: Teacher should give comments about their speech but teacher need to know when to give. Over correction might demotivate students to speak again and commenting them in the middle of conservation might distract them. So teacher need to provide proper feedback that might help them in a positive way to improve their speaking

skills.

\section{Importance of Speaking}

In learning any language speaking would be given more focus similar with English (Irtatik, 2009).So it is very important for students to master English speaking skills. The importance of English is emphasize as human use speaking so much in their daily life to carried out their daily activities or business. Speaking has given large contribution in human work(Irtatik,2009).Impromptu speaking occurs automatically once speaker obtain fluency and accuracy of the target language. Speaking involves real time and face to face conversation which leads to human connection(Irtatik,2009).Speaking varies in different situations, objectives, speakers just need to know suitable words to utter(Irtatik,2009).

\section{Definition of Language Games}

Language games is a fusion between language and play (Rooyavkers, 2002). According to Komensky (2015), games should be tool a language tool for children (Osobnosti.cz, n.d.). Games is define as an activity consist of rules, goal and element of fun (Hadfield, 1998). Language game defines as a meaningful fun activity comprise with rules and goal.Language 
game is categorize in two definitions, which is linguistic and communicative games. Linguistic game is mainly on accuracy whereas communicative game is about the exchange of information (Hadfield, 1998).

\section{Classification of Language Games}

These language games are classified by Hadfield (1998).

These games are as follows:

(a) Sorting, ordering, or arranging games.

(b) Information gap games

(c) Guessing games

(d) Search games

(e) Matching games

(f) Labelling games

(g) Exchange games

(h) Board games

(i) Role play games

(j) Computer games

According to (Jacob,n.d), there are two types of language games which is competitive games and cooperative games. In competitive game learners focus to achieve the goal whereas in cooperative game learners work together to achieve the goal of game. Games can be modified according to students' needs.

\section{Speaking Skills and Language Games}

In speaking classes, students are reluctant to speak but by using language games they would easily participate in speaking activities. Using games in classroom provides a different environment to students, they will mechanically accept participating. It is one of the advantages in speaking class because teachers always have to make sure students' participation. For students and teachers, games cater entertainment which excites students to be more competitive with each other. According Rixon (1981), game can be carried out by two ways, compete with each other or cooperate with each other to achieve the goal based on the limited rules.

Students goes through a lot stress and challenges in classroom when they learn speaking in second language as there are many speaking components such as pronunciation ,enunciation, rate of speech, pause filler. When comes to speaking, they feel pressured to speak within the topic learn however implementing games in classroom helps to reduce stress. This is due to the enjoyment and relaxation students get when they learn through language games. Children to adults, all enjoys game and it makes them less nervous when they are learning something. When students are playing language game they have to communicate using English, thus teacher can observe their speaking and gives feedback at the end of the lesson. Students tend to remember the mistake they did better because they were doing it while in a relaxed mode. Corrections given by the teachers would motivate them to do better in next game. In short, language games expose areas of weakness and strength of students' speech and helped teacher to view it better.

\section{Method}

Studies are based on analysis that were derived from international online bibliographic databases, named Google Scholar, Educational Resources Information Centre (ERIC), 
ScienceDirect, Springer e-journals and Sage. The research was focused on English written journals published in peer-reviewed journals, $\mathrm{PhD}$ dissertations and conference proceedings in the area of ESL language games, ESL speaking and language games. The range of research was limit from 2010 to 2019.Search terms were used to identify the literature, the keywords were (language games),(language games and English speaking skills) ,(language games in improving English speaking skills) and (ESL students' perception on language games) , (impact of language games on ESL students). The initial search yielded 170000 results and later on the title were screened based on the following criteria:

1. Publication had to provide specify information on games (title, type, genre, features).

2. All the participants in the research could be in their primary, secondary or tertiary levels.

3. Recruit English as a second language or foreign language participants.

4. Games implemented should be categorize as language games.

5. English language skills especially speaking skills should be taught by using games.

6. Studies could use various instruments to obtain the results.

7. The studies could use qualitative, quantitative, mixed- method or quasiexperimental research.

8. The setting of the implementation of language games must be school-bases.

Studies that are based on sub-skills of speaking for example vocabulary and grammar and studies based on communicative games, board games are included .Studies that are based on other skills and games, for instance listening, reading and writing o were excluded from the current literature review.

\section{Results and Discussion}

After following the procedures of conducting the systematic review that been mentioned in the sub topic earlier, a total of fourteen past related studies on use of language games enhance students' speaking skills from year 2010 to 2019 were shortlisted .Out of thirteen studies one were published in 2019 ,one were published in 2018 , four journals were published in 2017, two were published in 2016, two were published in year 2015, two were published in 2014, one were published in 2013, two in year 2012 and two were published in 2010. All the past related studies are summarized in Table 1,2 and 3 as follows.

\begin{tabular}{|c|c|c|c|c|}
\hline Article/Study & Number of participants & $\begin{array}{l}\text { Research } \\
\text { Design }\end{array}$ & Types of games & $\begin{array}{l}\text { Results (Impact of } \\
\text { games) }\end{array}$ \\
\hline $\begin{array}{l}\text { Fung\&Min } \\
(2016)\end{array}$ & $\begin{array}{l}60 \text { first-year students } \\
\text { from Polytechnic Melaka }\end{array}$ & $\begin{array}{l}\text { Quasi- } \\
\text { experimental } \\
\text { research }\end{array}$ & Board game & $\begin{array}{l}\text { (a)Board games is a } \\
\text { useful tool } \\
\text { to make students } \\
\text { involve. } \\
\text { (b)Board games helps to } \\
\text { enhance } \\
\text { the speaking ability of } \\
\text { low } \\
\text { proficiency students. } \\
\text { (c)Board games reduce } \\
\text { the anxiety of students. }\end{array}$ \\
\hline $\begin{array}{l}\text { Amal \& } \\
\text { Majeda(2014) }\end{array}$ & $\begin{array}{l}158 \text { first grade students; } \\
\text { (76) male students and }\end{array}$ & $\begin{array}{l}\text { Quantitative } \\
\text { Research }\end{array}$ & Word game & $\begin{array}{l}\text { (a) Word game } \\
\text { promotes }\end{array}$ \\
\hline
\end{tabular}




\begin{tabular}{|c|c|c|c|}
\hline & $\begin{array}{l}\text { (82) female students } \\
\text { during the first semester } \\
\text { of the academic year } \\
2013 / 2014 \text { from two } \\
\text { schools which are Marj } \\
\text { Al Hamam Primary } \\
\text { school for girls and Al } \\
\text { Baraa' School for boys in } \\
\text { Amman }\end{array}$ & & $\begin{array}{l}\text { motivation and } \\
\text { enjoyment } \\
\text { (b) Games is effective } \\
\text { tool to } \\
\text { enhance language } \\
\text { skills. } \\
\text { (c) Games involves } \\
\text { students' participation. }\end{array}$ \\
\hline $\begin{array}{l}\text { Wahyuni \& } \\
\text { Yulianti(2019) }\end{array}$ & $\begin{array}{l}27 \text { students from MAN } 3 \\
\text { Banda Aceh }\end{array}$ & $\begin{array}{l}\text { Qualitative Guessing game } \\
\text { Research }\end{array}$ & $\begin{array}{l}\text { (a) There are some } \\
\text { positive } \\
\text { impact shown by } \\
\text { students } \\
\text { through guessing } \\
\text { game. } \\
\text { (b) Guessing games } \\
\text { helped not } \\
\text { only in speaking skills } \\
\text { but } \\
\text { also increase } \\
\text { students' } \\
\text { confident. }\end{array}$ \\
\hline
\end{tabular}

Table 1: Summary of past studies that use one language game

\begin{tabular}{|c|c|c|c|c|}
\hline Article/Study & $\begin{array}{l}\text { Number of } \\
\text { participants }\end{array}$ & $\begin{array}{l}\text { Research } \\
\text { Design }\end{array}$ & $\begin{array}{l}\text { Types of } \\
\text { games }\end{array}$ & Results (Impact of games) \\
\hline $\begin{array}{l}\text { Alfulaih\&Elsye } \\
\text { d(2017) }\end{array}$ & $\begin{array}{l}50 \text { Saudi female } \\
\text { EFL students } \\
\text { from Saudi } \\
\text { Electronic } \\
\text { University (SEU). }\end{array}$ & $\begin{array}{l}\text { Quasi- } \\
\text { experimental } \\
\text { research }\end{array}$ & $\begin{array}{l}\text { 1.Truth } \\
\text { and Lie } \\
\text { 2.Guess } \\
\text { Who }\end{array}$ & $\begin{array}{l}\text { (a) Enhance students' speaking skills. } \\
\text { (b) Students feel more motivated to speak. } \\
\text { (c) Develop positive attitude towards } \\
\text { speaking English. }\end{array}$ \\
\hline $\begin{array}{l}\text { (Sochetra,2017 } \\
\text { ) }\end{array}$ & $\begin{array}{l}16 \text { teachers from } \\
\text { ACE Samdach } \\
\text { Pan, } 6 \text { teachers } \\
\text { from ACE } \\
\text { Santhor Mok, } \\
\text { and } 5 \text { teachers } \\
\text { from ACE Toul } \\
\text { Tom Poung. }\end{array}$ & $\begin{array}{l}\text { Mixed Method } \\
\text { research }\end{array}$ & $\begin{array}{l}\text { A list of } \\
\text { language } \\
\text { games }\end{array}$ & $\begin{array}{l}\text { (a) Useful tool for teachers to achieve } \\
\text { learning objectives. } \\
\text { (b) Students enjoyed the lesson. }\end{array}$ \\
\hline $\begin{array}{l}\text { Dewi,kulsum\& } \\
\text { Armadi(2017) }\end{array}$ & $\begin{array}{l}\text { English teacher } \\
\text { and } 36 \text { students } \\
\text { from the seventh } \\
\text { grade Junior High } \\
\text { School of } 6 \text { South }\end{array}$ & $\begin{array}{l}\text { Collaborative } \\
\text { action } \\
\text { research }\end{array}$ & $\begin{array}{l}\text { Variety of } \\
\text { language } \\
\text { games }\end{array}$ & $\begin{array}{l}\text { (a) Students enjoyed their lesson. } \\
\text { (b) Students gain more motivation and } \\
\text { confidence to speak } \\
\text { English. }\end{array}$ \\
\hline
\end{tabular}


Tangerang

Jakarta,

Indonesia.

\begin{tabular}{|c|c|c|c|c|}
\hline $\begin{array}{l}\text { Amrullah } \\
\text { (2015) }\end{array}$ & $\begin{array}{l}28 \text { students from } \\
\text { State Islamic } \\
\text { Senior High } \\
\text { Schools in Gresik }\end{array}$ & $\begin{array}{l}\text { Mixed method } \\
\text { research }\end{array}$ & $\begin{array}{l}\text { A book of } \\
\text { language } \\
\text { games }\end{array}$ & $\begin{array}{l}\text { (a) Students feel less pressure in speaking } \\
\text { English. } \\
\text { (b) Students feel very motivated. }\end{array}$ \\
\hline Nazirah (2015) & $\begin{array}{l}29 \\
\text { undergraduate } \\
\text { students from } \\
\text { Universiti } \\
\text { Malaysia Sabah }\end{array}$ & $\begin{array}{l}\text { Quantitative } \\
\text { Research }\end{array}$ & $\begin{array}{l}\text { 1.Quick } \\
\text { Quiz } \\
\text { 2.Mind } \\
\text { Your Head } \\
\text { 3. Time } \\
\text { Up! } \\
\text { 4.Spontan } \\
\text { eous Story } \\
\text { Telling }\end{array}$ & $\begin{array}{l}\text { (a) Through language games, non-verbal } \\
\text { usage shown. } \\
\text { (b) Emotion of students were expressed, } \\
\text { emotions like } \\
\text { confident, enjoyment and fun. }\end{array}$ \\
\hline Wang (2010) & $\begin{array}{l}\text { The participants } \\
\text { were } 150 \\
\text { teachers } \\
\text { teaching in } \\
\text { Taiwanese } \\
\text { primary schools }\end{array}$ & $\begin{array}{l}\text { Quantitative } \\
\text { Research }\end{array}$ & $\begin{array}{l}\text { Variety of } \\
\text { communic } \\
\text { ative } \\
\text { games }\end{array}$ & $\begin{array}{l}\text { (a) Students experience meaningful } \\
\text { conversation through communicative } \\
\text { languages. } \\
\text { (b) Communicative languages develop } \\
\text { speaking abilities in among students. }\end{array}$ \\
\hline Cheng(2018) & $\begin{array}{l}6 \text { students aged } \\
19-23 \text { who are } \\
\text { currently } \\
\text { enrolled in } \\
\text { speaking courses } \\
\text { at the low- } \\
\text { intermediate } \\
\text { level in the } \\
\text { Intensive English } \\
\text { program (IEP) at } \\
\text { the University of } \\
\text { Mississippi. }\end{array}$ & $\begin{array}{l}\text { Quantitative } \\
\text { Research }\end{array}$ & $\begin{array}{l}\text { Board } \\
\text { games } \\
\text { 1.Codena } \\
\text { me } \\
\text { 2.Apples } \\
\quad \text { to } \\
\quad \text { apples } \\
\text { 3.Dixit }\end{array}$ & $\begin{array}{l}\text { (a)Showed speaking improvement } \\
\text { (b)When students interact with each other } \\
\text { through games, their anxiety levels } \\
\text { decreased, but in an individual test setting, } \\
\text { they experienced an inherent level of } \\
\text { anxiety. }\end{array}$ \\
\hline
\end{tabular}

\begin{tabular}{|c|c|c|c|c|}
\hline Biloon (2016) & $\begin{array}{l}30 \text { university } \\
\text { students that are } \\
\text { in their fourth } \\
\text { semester doing } \\
\text { elementary } \\
\text { school teacher } \\
\text { course }\end{array}$ & $\begin{array}{l}\text { Qualitative } \\
\text { Research }\end{array}$ & $\begin{array}{l}\text { 1.Famous } \\
\text { name } \\
\text { game } \\
\text { 2.Board } \\
\text { game } \\
\text { 3.Board } \\
\text { rush } \\
\text { 4.Charades }\end{array}$ & $\begin{array}{l}\text { (a) Games boost motivation among students. } \\
\text { (b) Games help to improve speaking and } \\
\text { other learning skills. } \\
\text { (c) Games create a enjoyable environment. } \\
\text { (d) Games provides authentic learning. }\end{array}$ \\
\hline
\end{tabular}




\begin{tabular}{|c|c|c|c|}
\hline Study & $\begin{array}{l}\text { Number of } \\
\text { Participants }\end{array}$ & Type of game & $\begin{array}{l}\text { Results(perception } \\
\text { of students on } \\
\text { language games) }\end{array}$ \\
\hline Sasidharan\&Eng (2013) & $\begin{array}{l}56 \text { students } \\
\text { from Malaysian } \\
\text { primary school } \\
\text { aged } 11 \text { and } 12 \\
\text { years old }\end{array}$ & $\begin{array}{l}\text { Language Board } \\
\text { Game(CHALLENGE) }\end{array}$ & $\begin{array}{l}\text { Students gave a } \\
\text { positive response } \\
\text { after playing the } \\
\text { game. }\end{array}$ \\
\hline $\begin{array}{l}\text { Chrandon,Laohawiriyanon } \\
\text { \&Rakthong,(2010) }\end{array}$ & $\begin{array}{l}33 \text { students of } \\
\text { grade six at } \\
\text { Tessaban } 4 \\
\text { Banlamsai } \\
\text { School }\end{array}$ & $\begin{array}{l}\text { 1.Whispering } \\
\text { games } \\
\text { 2. Hello Game and } \\
\text { Nice to meet you } \\
\text { 3. Giving clues and } \\
\text { fishing } \\
\text { 4. Who am I and } \\
\text { missing } \\
\text { information } \\
\text { 5. Fishing }\end{array}$ & $\begin{array}{l}\text { Students show } \\
\text { preference towards } \\
\text { language games. }\end{array}$ \\
\hline laremenko (2017) & $\begin{array}{l}120 \text { students ( } 76 \\
\text { boys and } 44 \\
\text { girls) } \\
\text { Between } 18 \text { to } \\
22 \text { years old } \\
\text { from National } \\
\text { University of Life } \\
\text { and } \\
\text { Environmental } \\
\text { Sciences of } \\
\text { Ukraine in Kyiv }\end{array}$ & $\begin{array}{l}\text { Online learning } \\
\text { games }\end{array}$ & $\begin{array}{l}\text { Most of the students } \\
\text { enjoyed playing } \\
\text { games and they } \\
\text { developed positive } \\
\text { feelings towards } \\
\text { games. }\end{array}$ \\
\hline
\end{tabular}

Table 3: Summary of past studies that shows students' response towards language games

\section{The Effectiveness of Language Games among ESL Students}

Through the systematic review, all the ten journals are divided into two tables. One table for studies that used only one language games in their research and another table is about journals used more one language games in their research. There are three studies used only a single game to teach language skills, the studies were from (Fung\&Min,2016;Amal\&Majida,2014;Wahyuni,2019).By looking overall, most of the studies shows a positive effect of learning language using games not only on students but also on teachers. Based on the outcome of analysis of all these research, effectiveness of games varies from each other however there are also studies that shared the same effect of language games(Alfulaih\&Alsyaayed,2017;Dewi, Kulsum\&Armadi, 2017; Amal \&Majida, 2014;Biloon,2016;Amarullah,2015) shares the same positive effect which is increase motivation among students. 
Language games promotes the joy that makes students enjoy the English lesson, there are few studies shares same results (Sochetra, 2017; Dewi, kulsum\&Armadi, 2017; Nazirah, 2015; Amal \& Majida, 2014), Based on results of Biloon (2016), language games creates an enjoyable learning environment for ESL students. Based on the studies of (Biloon, 2016; Wang, 2010), students get to experience real life communication with their peers through games, as they learn how to apply the knowledge of second language that they learn hence it would boost their confidence.

There are also few studies display implementation of language games helped reduced the issues of anxiety among students (Fung, 2016; Cheng, 2018), and both studies used board games in their lessons. According to the data analysis by Cheng (2018), board games involves communicating with peers thus it helped the anxiety to ablated however the students still experience anxiety in test setting. All the ten studies involved different age and background of participants. There are studies by Sochetra, (2017), Wang (2010) that involved only teachers as their participants. These studies carried out their studies on teacher that used language game in teaching and learning English process. There is one study by Dewi,Kulsum \&Armadi (2017) that uses teachers and students as participants. Researcher conducted an action research that involves English teacher and students. In this study by Dewi,Kulsum \&Armadi (2017), English teacher act as a observer and researcher becomes teacher. English teacher is responsible to jot down the observation when students are playing the language game in classroom.

Different execution of language games and different types of language games used provides different positive effects of language games. Based on the systematic review, the impacts of using language games in classroom settings are as follows 1.gained confidence and motivation 2.Involves students to participate in lesson 3. promotes enjoyment and fun 4.Less anxiety faced 5.provide real life communication. Generally all these positive effects has help students to enhance their speaking skills in English.

\section{Language Games Increase Motivation and Confidence of ESL Students}

Language teacher always faced challenges to teach second or foreign language especially speaking, teacher have to teach and ensure students feel motivated simultaneously. Thus language games can be a useful teaching tools based on the reviewed studies by Amal \& Majida(2014).According to Mubaslat (2012), games can be used to teach English as it is motivating because they have the combination of amusing and challenging at the same time. The motivation in students develop when they want to be one that complete the task earlier than anyone to win the game (Mubaslat,2012). Thus they would have healthy competition that would push them to learn English.In study of Wang (2010) he cited (Wright, Betteridge, \& Buckby,2005), language games are motivating and Adams (1983) stated that games are selfmotivating to develop students' interest and curiosity which sustain their interest to play language games in the beginning stage of learning.

\section{Language Games Encourages Students' Involvement in Lessons}

ESL students do not participate in the speaking lesson because they would feel shy, bored and not interested. Language games allows students to develop their interest towards the language because it consist of fun element. Since language games viewed as to be played in relaxed mode, students would feel interested.Allowing students to be interested towards the 
lesson is a sustaining effort (Thiagarajan, 1999; Wright, Betteridge, \& Buckby, 2005). As the lesson becomes interesting to students, they would voluntarily participate in the lesson. Results collected from Amal\&Majida (2014) concludes language game is a teaching method that encourages students' active participation in classroom.

\section{Language Games Promotes Enjoyment and Fun}

Sochetra (2017) has a section about teacher's perception in using language games in classroom, He cited Yahoui(2002) stated, different teachers would have their own thoughts in using language but majority of teachers accept language games as language strategy. Teachers also believe language games promotes enjoyment and fun in the classroom. These studies shows the same response as Sochetra (2017), Dewi, Kulsum \& Armadi (2017), Nazirah (2015), Amal \&Majida (2014). When students participate to play games, a lot of excitement stimulated which form a positive response as emotions aroused is part of the process of language instruction (Bransford,Brown \&Cocking,2000; Ersoz, 2000;Lee,1995).In study of Wang(2010) he cited from Krashen(1982),Games are activities that consist of meaningful and playful element that arouse excitement among learners hence it motivate them to learn.

\section{Through Language Games Anxiety can be Reduced among ESL Students}

Cheng (2018) cited Woodrow (2006) on classification on four types of anxiety in his study, trait anxiety, state anxiety, and situation specific anxiety. Trait anxiety occurs when a person feels anxious in many different situations, state anxiety occurs during a particular moment and situation specific anxiety happens in class during special situations. Speaking foreign or second language anxiety is classified in situation special anxiety (Horwitz \& Young, 1991; Baker \& Macintyre, 2003; Windrow, 2006)

Language anxiety is related to foreign language anxiety or speaking in second language, as when students join speaking class they with experience anxiousness in any classroom environment (Horwitz, 2001).

Language anxiety gives a negative impact on ESL students as Cheng (2010) cited few related past studies that supports the statement. Past related study from Horwitz\& Cop e(1986) found out anxiety in students lead to fear of speaking in foreign or second language class and research from Phillips(1992) stated that language anxiety affects students oral abilities. In addition study from Masgoret, Bernaus\& Gardener (2001) revealed the significant relationship between language anxiety and English achievement in classroom. However, Cheng (2010); cited Zhu (2012) stating students' anxiety level can be lowered by using games in English language classroom as they can in a calm state when they learn English. These findings were similar with results of Cheng (2010), during the pretest students were reluctant to speak but after using games their anxiety level is reduced. One of the students stated that when they are busy playing games in a group, they forget that they are using English hence their focus will be on games more than thinking about what to speak in English (Cheng, 2010).

\section{Students Experience Real Life Communication through Language Games}

In study of Wang (2010), he listed characteristics of communicative games. Through language games, students able to get exposure of the real life conversation of English as traditional teaching methods forbids language use. Wang (2010) cited Krashen's (1982) idea that indicate language learning occurs from using the language in speaking rather than just focusing the grammar. Through language games, learners are given opportunity to interact with others 
using English in order to get meaning or exchange information (Larsen, 2000; Littlewood 1981; Widdowson, 1979).

Biloon (2016) also supported this statement as he stated learning speaking means speaking in real life situation context so students are able to connect the target language with real life conversation. This only can occur by playing games that involves speaking skills. To support the idea, he cited Lombardi (2007) that expressed exposing to students real life conversations would increase their confidence towards the material of language learning. Biloon (2016) added Deesri (2002) study that students in the study become focused and working together as a group to win the game and without students' awareness using of grammar and vocabulary happen naturally. Speaking happens in spontaneously and naturally when students are not thinking about the language (Deesri, 2002). Biloon(2016) cited Chen(2005) which added how learning language skills through language games is related to real life and it helps students to apply these skills outside of the classroom. Thus speaking should be taught using meaningful and purposeful context so students could use it to communicate with other outside of the classroom settings (Littlewood, 1981).

\section{ESL students' Point of view on Language Games}

Three related studies were found about students' perception towards games. One of the study conducted by Chrandon, Laohawiriyanon \& Rakthong (2010), involves a number of 33 grade six Thailand students from Tessaban 4 Banlamsai. Students were introduced to five language games through the research which were whispering games, hello game and nice to meet you, giving clues and fishing, who am I and missing information and fishing. After they played all of these games, students were given questionnaire to find out students' view in playing language games at the same time researcher used other activities too to teach language skills. Based on the questionnaire, most of the students prefer language games as a teaching method compared to other methods that researcher used which are reciting vocabulary, consulting dictionary, vocabulary dictation, repeating conversation and reciting English conversation .Chrandon,Laohawiriyanon \& Rakthong (2010) cited similar study that showed the same results, study conducted by Rama (1994) involves 78 students of grade four which divided into two groups. Based on the data analysis, those students learn English through language games had a better effect and attitude towards learning English compared to those who learn traditional method.

Another research conducted by Sasidharan\&Eng (2013) which involves a number of 56 students aged 11 to 12 years old from Malaysian primary school. In this research Sasidharan\&Eng (2013) developed a language board game called CHALLENGE. This game mainly focuses on speaking skills and this game were played few times with the students. Students were given questionnaire and selected students went through semi-structure interview to investigate students' view towards the board game. Based on the data collected, most of the students agree with the statement that game promotes teamwork, it required strategies to win the game and also motivates students to learn English (Sasidharan\&Eng, 2013). However there were also students agreed with the statement they took long time to understand how to play the game. Sasidharan \& Eng (2013), concluded that the language board game is effective to teach ESL students with a clear rules (Sasidharan \& Eng, 2013) 
Latest study carried out by laremenko (2017) which involves 120 students, 76 students were boys whereas 44 of them were girls. These students were from National University of Life and Environmental Sciences of Ukraine in Kyiv. Students were introduced to online games to learn language skills. Students were given a series questionnaire which consist of to rate the game, students' feelings during they were playing the game. Students were also given questionnaire to evaluate students' motivation and component of intrinsic motivation after playing the online game. Based on the data collected, $90 \%$ of students choose to recommend games as learning tool. In addition, $87 \%$ of the students had positive feelings, $11 \%$ felt neutral and $2 \%$ had negative feelings during and after playing the game. Based on the results laremenko (2017) stated that students value clear rules of the games and online game offers other advantages as well for example it helps to developed calm learning environment even though if the students experience failure, grab students' attention and provide fun and competitive environment.

\section{Conclusion}

Based on the related past studies, use of language games in classroom always provides benefits as similar as cited by Savitri (2013), She cited a summary of benefits of using language games from Savigon \& Bern (1987).According to Savigon\& Bern(1987), there are three main advantages of using language games in teaching second or foreign language. The structure of language games get students to use the language rather than just practicing in a classroom context (Savigon \& Bern, 1987). Real life communication takes place when students interact with each other using the target language. In addition language games helps teachers to create a relaxed environment (Savigon\&Bern,1987). When students are learning in a calm environment ,they would totally stay focus and it would also lowered students' stress and anxiety(Savigon\&Bern,1987). The benefits of playing games is correlated with the problems faced by students. For example when they are focused they would be more motivated and they would be more competitive. Savigon\&Bern (1987) added language games makes students understand the use of language.

Korkmaz(2012) cited MCFarlane et al (2002) stated that apart from teachers, parent realized the importance of games in classroom. Games assist students to develop development skills such as creative thinking, strategic thinking, communication, negotiating skills which matches with the studies of (Korkmaz, 2012). Korkmaz (2012) concluded students do gain positive effects from language games. Based on all the related past studies, language games gives a positive impact on students' language skills especially speaking. Most of the games involves speaking thus students somehow would be practicing the language. According to the analysis of the past studies, it is shown that any kind of language games which consist of clear rules, objectives and suits the students' need would enhance their speaking skills no matter the age of students. The past related studies involves studies that are from primary to tertiary level, yet games did not fail to big positive differences among students as stated by Uberman(1998), "games encourage, entertain , teach and promote fluency and speaking skills".

As conclusion language games do play an important role in speaking lessons. Through this research we can conclude that language games acts as an assistant to teachers and educators. It adds the element of fun and promotes real life interaction among learners. Through this study, it gives idea to teachers and educators on how to implement different language games in their classroom .Furthermore, Teachers can also adapt and adjust the language games 
according to the learners' need. Teachers could also study the learners' speaking proficiency level after the implementation of games.

\section{Limitations and Recommendation for Future Research Studies}

Though the results of this systematic review displays the positive impact of using language games to teach English speaking skills among ESL students, two limitations of this review will be recognize. The first limitation is some of the past study as did not elaborate or mention specifically the language games that they used in research. Thus it did not provide sufficient information. Secondly there were insufficient time limit to gather all the information for this systematic review.

\section{Aknowlwdgement}

Firstly I would like to thank my supervisor Dr. Azlina Abdul Aziz of the Faculty of Education at the National University of Malaysia. She has consistently gave me guidance whenever I have questions regarding my research .I also would like to thank her for giving me this opportunity to carried out and complete this research.

Secondly I would like to thank my batch mates. They keep motivating me to complete this research paper. They also shared some information regarding research on education.

Finally, I would like to express my gratitude to my parents and my siblings for providing me a great support through the process of completing this research. It is not possible to achieve this accomplishment without them. Thank you.

\section{References}

Ahmad, S. R. (2016).Importance of English communication skills.International Journal of Applied Research, 2(3),478-480.

Alfulaih, W. K. (2017). The impact of using games on developing Saudi female EFL students' speaking skills. English Language and Literature,1 -98.

Amal, A. M., Majeda, A. N. (2014).The effect of using Word games on primary stage students achievement in English language vocabulary in Jordan.American International Journal of Contemporary Research,4(9),144-152.

Amrullah, A. Z. (2015). Developing language games to teach speaking skill for Indonesian Senior High School Learners. JEELS, 2 (2), 13-33.

Baker, S. C., Macintyre, P. D. (2003). The role of gender and immersion in communication and second language orientations. In Z. Dörnyei (Eds.), Attitudes, Orientations and Motivations in Language Learning. Malden, MA: Blackwell publishing.

Baker, J., \& Westrup, H. (2003). Essential Speaking Skills: A Handbook for English Language Teachers. London: Continuum.

Bamford, K. W., \& Mizokawa, D. T. (1991). Additive-Bilingual (Immersion) Education: Cognitive and Language Development. Language Learning, 41 (3), 413-429.

Biloon, A. S. (2016).Different reasons to play games in an English language class.Journal of Education and Training Studies, 5(1), 84-93.

Cheng, Y-C. (2018).The effect of using board games in reducing language anxiety and improving oral performance.Electronic Thesis and Dissertations :University of Mississippi.

Chirandon, A., Laohawiriyanon, C., \& Rakthong, A. (2010).The effect of teaching English through games.The 2 nd International Conference on Humanities and Social Sciences. 
Darwish, S., Alzayed, S., \& Ahmed, U. (2020). How Women in Science can Boost Women's Entrepreneurship: Review and Highlights. International Journal of Innovation Creativity and Change, 14(1), 453-470.

Dewi, S. D., Kultsum, U., Armadi, A. (2016). Using communicative games in improving students' speaking skills. English language teaching, 10 (1),63-71.

Diana. (2012).Why is learning English so Beneficial nowadays?.International Journal of Communication Research, 2(4), 374-376.

Deesri, A. (2002).Games in the ESL and EFL class.Retrieved June 4,2020 http://iteslj.org/Techniques/Deesri-Games.htm

Fung, Y. M., Min, Y. L. (2016).Effects of board game on speaking ability of low-proficiency ESL learners .International Journal of Applied Linguistics \& English Literature, 5 (3),261271.

Fung, Y. M., Min, Y. L. (2016). Effect of board game on speaking ability of low proficiency ESL learners. International Journal of Applied Linguistics \& English Literature, 5(3), 261-270.

Gate, M. (2003). Language Teaching: A Scheme for Teacher Education; Speaking. Oxford: Oxford University Press.

Hadfield, J. (1998). Elementary vocabulary games. Harlow: Pearson Education.

Hamad, M. M. (2013). Factors negatively affect speaking skills at Saudi Colleges for girls in the South. English Language Teaching, 6(12),87-97.

Hang, S. (2017). Using games to teach young children English Language. Psychology \& Educational Sciences, 1-78.

Harmer, J. (2001). The Practice of English Language Teaching (3rd ed.). Edinburgh: Longman. Harmer, J. (2007). How to Teach English. Pearson Education Limited.

Harmer, J.(2001).The Practice of English Language Teaching.Great Britain: Pearson Education.

Harris, C. (2006). Meet the new school board: board games are back - and they're exactly what your curriculum needs. School Library Journal, 55(1), 24-26.

Harry, A. (2006). An A to Z Practical Guide to Learning Difficulties. New York:David Fulton Publishers.

Horwitz, E. K. (2001). Language anxiety and achievement. Annual Review of Applied Linguistics, 21,112-126.

Hubbard, J. (1987).A Training Course for ELT. Oxford: Oxford University Press.

laremenko, N. V. (2017). Enhancing English language learners' motivation through online games.Information Technologies and Learning Tools ,59(3),126-133.

Korkmaz, S. C. (2012).Language game as part of edutainment.Social and Behavioral Science ,93(2013),1249-1253.

Krashen, S. D.(1982).Principles and Practice in Second Language Acquisition.Oxford: Pergamon.

Kukulska-Hulme, A., Pettit, J., Bradley, L., Carvalho, A. A., Herrington, A., Kennedy, D., \& Walker, A. (2011). Mature students using mobile devices in life and learning. International Journal of Mobile and Blended Learning,3(1),18-52.

Larsen-Freeman, D.(2000). Techniques and Principles in Language Teaching.Oxford: Oxford University Press.

Lee, W. R. (1965).Language Teaching Games and Contests.London: Oxford University Press. Lewis, G., \& Bedson, G. (1999). Games for children. Oxford: OUP.

Littlewood, W. (1981).Communicative Language Teaching: An Introduction.Cambridge: Cambridge University Press. 
Lombardi, A. (2007). Authentic Learning for the 21st Century: An Overview. Retrieved June 3, 2020, from https://library.educause.edu/resources/2007/1/authentic-learning-forthe-21st-century-an-overview

MacKenty, B. (2006). All play and no work. School Library Journal, 52(2), 46-48.

Mahmoud, A. A. A., \& Tanni, Z. A. (2014). Using games to promote students motivation towards learning English, Al-Quds. Open University Journal for Educational \& Psychological Research \& Studies, 2(5).

Masgoret, A-M., Bernaus, M., \& Gardner, R. C. (2001). Examining the Role of Attitudes and Motivation Outside of the Formal Classroom: A Test of the Mini-AMTB for Children. In Z. Dörnyei \& R. Schmidt (Eds.), Motivation and Second Language Acquisition. Honolulu: University of Hawai'i, Second Language Teaching and Curriculum Center.

Mubaslat,M.(2012).The effect of using educational games on the students' achievement in English language for the primary stage. http://files.eric.ed.gov/fulltext/ED529467.pdf[1 June 2020].

Nunan, D.(1995).Language Teaching Methodology : a Textbook for teachers. New York:Phoenix.

Oprandy, R. (1994).Listening/ Speaking in Second and Foreign Language Teaching. System, 22(2), 153-175.

Phillips, S. (1993). Young learners. Oxford University Press: Oxford.

Phillips, S. (1999). Drama with Children. Oxford University Press.

Pop, Anamaria-Mirabela. (2011). Teaching English to Business Students - A Challenge for the 21st Century' in Foreign Languages, Specialized Communication and Intercultural Phenomena III, International Scientific Conference organized by the Centre of Languages for Special Purposes, College of International Entrepreneurship ISM Slovakia, Presov.

Ridwan, W., \& Zahariah, P. (2017). Learning English in a third Space? Malay students in an English-Speaking University in Malaysia. Pertanika Journal, 20(3), 1167- 1180.

Rivers, W. (1981). Teaching Foreign Language Skills (2nd ed.). Chicago: University of Chicago Press.

Rixon, Steven. (1981). How to Use Games in Language Teaching. London: Macmillan.

Rooyackers, P. (2002).101 language games for children: Fun and learning with words, stories and poems. USA, CA: Hunter House Inc.

Sasidharan, A., \& Eng, T. K.(2013).Pupils' and teachers' perceptions of a language board game, challenge. The English Teacher,42(3),126-133.

Savitri, A. S.(2013).The use of language games to improve the students' speaking ability of class VII AOF AMP Ma'arif terpadu Muntilanin The Academic year of 2012/2013.Thesis Degree, University of Yogyakarta.

Shaaban, K. A., \& Ghaith, G. (2000).Students motivation to learn English as foreign language.Foreign Language Annals, 33(6),632-644.

Sochetra, H. (2017). Using games to teach young children English language.Master Thesis:Vrije University of Brussel.

Thornbury.S. (2005). How to Teach Speaking.United States of America:Pearson.

Torky, S. A. E.(2006).Thesis Phd,Ain Shams University.

Uberman, A. (1998). The use of games for vocabulary presentation and revision. English Teaching Forum, 36(1),20-27 
Wang,Y. H.(2010).Using communicative language games in teaching and learning English in Taiwanese primary schools.Journal of Engineering Technology and Education,7(1),126142.

Widdowson, H. G. (1979).Teaching language as communication, In Brumfit, C. J. \&Johnson, K. (eds.), The Communicative Approach to Language Teaching.Oxford: Oxford University Press.

Woodrow, L. (2006). Anxiety and speaking English as a second language. RELC Journal, 37(3), 308-328.

Wright, A., Betteridge, D., \& Buckby, M.(1984).Games for Language Learning.Cambridge: Cambridge University Press.

Yahoui, N. (2012). The Effectiveness of Language Games in Improving Learners' Vocabulary. Biskra: University of Biskra.

Zhu, D. (2012). Using games to improve students' communicative ability. Journal of Language Teaching and Research, 3(4) ,801-805. 